(C) The Author(s) 2020. Published by Cambridge University Press for the British Institute of International and Comparative Law. This is an Open Access article, distributed under the terms of the Creative Commons Attribution-NonCommercial-NoDerivatives licence (http://creativecommons.org/licenses/by-nc-nd/4.0/), which permits non-commercial re-use, distribution, and reproduction in any medium, provided the original work is unaltered and is properly cited. The written permission of Cambridge University Press must be obtained for commercial re-use or in order to create a derivative work.

\title{
REGULATING GENOME EDITING UNDER INTERNATIONAL HUMAN RIGHTS LAW
}

\author{
RuMiana Yotova*
}

\begin{abstract}
This article offers a critical assessment of the role of international human rights law in the regulation of genome editing. Given the rapid scientific developments in the field of genetics, it is important to explore the implications of the human rights framework for the research into and the clinical application of genome editing. The broader normative question is whether the existing human rights standards are sufficient to address the challenges posed by this new technology. It will be argued that while international human rights law does not prohibit genome editing, it imposes important restrictions upon it. However, existing human rights are arguably insufficient to regulate germline genome editing as there are significant loopholes in the protection of embryos. Nor do they fully address the wide-ranging implications of the new technology for society and humankind. It will be suggested that new standards are needed, ideally set out in a new international instrument and supported by an institutional framework, which address the specific challenges posed by this new technology.
\end{abstract}

Keywords: public international law, international human rights law, genome editing, science, new technologies.

\section{INTRODUCTION}

\section{A. Scientific Background and Recent Developments}

In November 2018 the Chinese scientist Dr He Jiankui announced the birth of the first genetically engineered babies-Lulu and Nana. This was the result of his editing and implanting of the embryos of seven couples with HIV-positive fathers in an attempt to make them resistant to the virus. ${ }^{1}$ The experiment was conducted in a private hospital in violation of China's non-binding ethical guidelines prohibiting heritable genome editing. ${ }^{2}$ The announcement was met

* Dr Rumiana Yotova is a Fellow and Director of Studies in Law at Gonville \& Caius College and a University Lecturer at the Faculty of Law of the University of Cambridge, rvy21@cam.ac.uk.

1 'World's First Gene-Edited Babies Created in China' The Guardian (26 November 2018) at: $<$ https://www.theguardian.com/science/2018/nov/26/worlds-first-gene-edited-babies-created-inchina-claims-scientist>.

2 Art 3(9) of China's Technical Norms on Human Assisted Reproductive Technologies (2003). 
with universal condemnation by scientists and international organisations, ${ }^{3}$ strongly indicating that clinical research involving genome editing is not considered acceptable at present. The Statement of the Second International Summit on Human Genome Editing where the experiment was first announced said that 'the procedure was irresponsible and failed to conform with international norms'. ${ }^{4}$ Similar concerns were expressed by the Chinese Academy of Medical Sciences, ${ }^{5}$ the French National Academy of Medicine and the Academy of Sciences ${ }^{6}$ and the UK Nuffield Council on Bioethics. ${ }^{7}$ In October 2019, the Russian scientist Denis Rebrikov reported editing human eggs to prevent deafness with the intention of using them to bring about a pregnancy. ${ }^{8}$ These experiments raise pressing questions regarding the permissibility and current regulation of human genome editing under international law, which will be explored in this article.

Since the discovery of the structure of the human genome in 1953 by Francis Crick, James Watson and Rosalind Franklin, ${ }^{9}$ scientific developments in genetics have been accelerating quickly. The 1990s saw the first clinical trials of gene therapies aimed at treating rare genetic disorders caused by a singlegene mutation. ${ }^{10}$ This promise of revolutionising healthcare led to a surge of regulatory action on the domestic and international planes. ${ }^{11}$ However, optimism soon turned to caution due to inconsistent results and the first death caused by a gene therapy clinical trial in $1999 .{ }^{12}$ Shortly afterwards, in 2003 , the

3 World Health Organization, Statement on Governance and Oversight of Human Genome Editing (26 July 2019) at: <https://www.who.int/news-room/detail/26-07-2019-statement-ongovernance-and-oversight-of-human-genome-editing $>$. See also D Cyranoski et al., 'International Outcry over Genome-Edited Baby Claim' (2018) 563 Nature 607.

4 Statement by the Organizing Committee of the Second International Summit on Human Genome Editing (November 2018) para 8.

5 Chinese Academy of Medical Sciences, 'Gene-edited Babies: Chinese Academy of Medical Sciences' Response and Action' (3 December 2018) at: <https:/www.thelancet.com/action/ showPdf?pii=S0140-6736\%2818\%2933080-0>.

6 A Declaration of the Académie nationale de médicine and of the Académie des sciences concerning the announcement made by Dr He Jiangkui (28 November 2018).

7 Nuffield Council Statement on reports of gene-edited babies born in China (26 November 2018).

${ }^{8}$ D Cyranoski, 'Russian Scientist Edits Human Eggs in Effort to Alter Deafness Gene' (2019) 574 Nature 465.

9 L Pray, 'Discovery of DNA Structure and Function: Watson and Crick' (2008) 1(1) Nature Education 100.

10 National Human Genome Research Institute, 'Results from First Human Gene Therapy Clinical Trial' (1995) at: <https://www.genome.gov/10000521/1995-release-first-human-genetherapy-results $/>$.

111997 UNESCO Universal Declaration on the Human Genome and Human Rights (11 November 1998); and the Oviedo Convention for the Protection of Human Rights and Dignity of the Human Being with regard to the Application of Biology and Medicine (4 April 1997) ETS No. 164. 12 Historic Overview of Gene Therapy at: <http://www.genetherapynet.com/patientinformation.html>. 
full sequencing of the human genome was completed and made publicly available. $^{13}$

In 2012 Charpentier and Doudna developed a new, significantly cheaper and more precise method of genetic engineering - genome editing through the CRISPR Cas9 tool, based on the mechanism used by bacteria to defend themselves against viruses. ${ }^{14}$ Genome editing is used to alter a selected section of DNA in a living cell by cutting the DNA at a chosen point and either deleting existing elements of the genome or introducing a new sequence. At present, the outcomes of human genome editing are far from certain. On the one hand, the use of the new tool frequently causes extensive unintended off-target mutations which 'could lead to important genes being switched on and off'. ${ }^{15}$ The other major safety challenge to the successful use of genome editing is 'mosaicism', where only some cells carry the desired edit. ${ }^{16}$ On the other hand, genome editing holds significant promise. According to the World Health Organisation, there are over 10,000 monogenic diseases caused by an error in a single gene of the DNA, ${ }^{17}$ which occur in 1 per cent of births. ${ }^{18}$ Some of these diseases are fatal and many significantly reduce the quality of life. ${ }^{19}$ Once sufficiently developed, genome editing could help alleviate and even eradicate the suffering caused by these diseases by inactivating a disease-causing gene or correcting a harmful mutation. In future, such new technology could also be used to address more complex disorders caused by mutations in multiple genes, such as cancer, cardiovascular diseases or diabetes.

Genome editing can be performed either on the somatic cells making up the body or on germline cells, such as those making up the early embryo, which contain the genetic information passed on to future generations. The latter type of human genome editing is more effective because it can be performed on a single-cell embryo with the potential to edit all of its genetic make-up in a heritable manner. However, germline editing raises the most difficult regulatory and ethical issues given the uncertainties involved in the use of this new technology, the irreversibility of the edits and the fact that any desired but also unintended negative changes would be passed on to future generations, with the potential of impacting humanity as a whole.

\footnotetext{
13 National Human Genome Research Institute, 'The Completion of the Sequence and Remaining Goals' (2012) at: <https://www.genome.gov/12011241/the-completion-of-thesequence-and-remaining-goals/>.

${ }^{14}$ M Jinek et al., 'A Programmable Dual-RNA-Guided DNA Endonuclease in Adaptive Bacterial Immunity’ (2012) 337(6096) Science 816.

15 M Kosicki et al., 'Repair of CRISPR-Cas9 - Induced Double-Stranded Breaks Leads to Large Deletions and Complex Rearrangements' (16 July 2018) 36 Nature Biotechnology 765.

${ }^{16}$ National Human Genome Research Institute, 'What Are the Ethical Concerns about Genome Editing?' at: <https://www.genome.gov/27569225/what-are-the-ethical-concerns-about-genomeediting/>. $\quad 17 \mathrm{See}<\mathrm{http}: / /$ www.who.int/genomics/public/geneticdiseases/en/index2.html $>$. 18 ibid.

19 Examples include thalassaemia, sickle cell anemia, haemophilia and cystic fibrosis.
} 
Furthermore, editing embryos carries an inherent level of risk as it is technically impossible to determine whether they carry unintended off-target mutations without destroying them while inspecting all of their cells. ${ }^{20}$ Another important distinction in this context is between basic research, involving genome editing to help understand the functions of genes and their relationship with diseases, and clinical research which uses genome editing for the treatment of diseases. With respect to germline editing, clinical research would involve implanting an edited embryo or bringing about a pregnancy with edited reproductive cells, whereas basic research would involve embryos in vitro and not result in a pregnancy.

In 2015, Chinese scientists reported using genome editing for the first time on non-viable human embryos to edit out a blood disorder. The intended editing had a less than 20 per cent success rate. ${ }^{21}$ Indeed, expert analysis of Dr He's unpublished manuscript on the Lulu and Nana experiment indicates that the team failed to reproduce the known mutation of the targeted gene and instead created a new one with unknown consequences. ${ }^{22}$ There were also unintended off-target mutations. ${ }^{23}$

Given the unique challenges and opportunities presented by human germline editing (hereinafter 'genome editing') the research into and the clinical application of this new technology are the focus of this article.

\section{B. Legal Issues Arising from Genome Editing}

Given the rapid acceleration of scientific developments regarding genome editing and the ease with which people can cross borders to access new healthcare technologies, there is an urgent need for an international debate and a consensus on the minimum regulatory standards that should apply to editing the human genome. It is essential that this takes place before genome editing routinely becomes clinically available somewhere in the world, at which point effective regulation to ensure the safe and ethical use of the new technology would become very difficult to implement in practice. ${ }^{24}$ The pressing need for regulation is reinforced by Dr He's recent experiment. Scientists and the WHO have called for a global moratorium on heritable genome editing until its implications have been properly considered, ${ }^{25}$ as well as for the establishment of an international framework imposing conditions that ought to be met before any use of genome editing can be

\footnotetext{
20 A Regalado, 'China's CRISPR Babies: Read Exclusive Excerpts from the Unseen Original Research' (3 December 2019) MIT Technology Review at: <https://www.technologyreview.com/s/ 614764/chinas-crispr-babies-read-exclusive-excerpts-he-jiankui-paper/>.

21 P Liang et al., 'CRISPR/Cas9-Mediated Gene Editing in Human Tripronuclear Zygotes' (2015) 6(5) Protein \& Cell 363.

22 Regalado (n 20).

24 P Berg, 'Asilomar 1975: DNA Modifications Secured' (2008) 455 Nature 290, 291.

25 WHO Statement on Governance and Oversight of Human Genome Editing (n 3).
} 
approved. $^{26}$ The fact that international human rights law already sets out important requirements and limitations on genetic interventions is largely overlooked in the present policy debates.

The aim of this article is to assess the international human rights framework that currently regulates the research and clinical applications involving genome editing and to analyse its implications for the use of the new technology. Particular emphasis will be placed on the challenges posed by the scientific and technological advancements regarding genome editing, in order to draw conclusions as to the adequacy and effectiveness of the current regulation. Building on this, normative suggestions will be made concerning the possible future development of international law in the area of biomedicine. Domestic law comparisons fall outside the scope of this study due to the constraints of space, though they undoubtedly merit a thorough further investigation.

The key questions are whether genome editing is currently prohibited or otherwise regulated under international human rights law? What are the relevant human rights norms and standards that apply to it? Is the existing international regulatory framework sufficient or are new standards - if not a new framework specifically designed to address genome editing-needed? What guarantees can be put in place to ensure that the new technology is safe to use before it is made clinically available? And finally, how can international law help balance the risk/benefit analysis with respect to the autonomy and welfare of the individual on the one hand, and the interests of society and humankind on the other?

It will be argued that international law is the most appropriate legal order through which to channel a consensus and develop a regulatory framework for genome editing, by helping harmonise domestic laws, setting out common minimum standards, providing centralised oversight and promoting good practices through soft law. This is because international law is the only overarching legal order that has the necessary procedures to help form and implement an international consensus on matters of common interest and concern. International law has a strong humanitarian focus, particularly since the end of the Second World War ${ }^{27}$ and has developed the tools necessary to balance the welfare of the individual with the interests of humanity as a whole, through concepts including proportionality, the common heritage of mankind, global public goods and the rights of future generations. Finally, international law has the capacity to regulate both the behaviour of States and of non-State actors across national borders, thus addressing the challenge of health tourism to States with the weakest domestic regulation.

26 E Lander et al., 'Adopt a Moratorium on Heritable Genome Editing' (2019) 567 Nature 165.

27 See eg Preamble, art 1(2) and art 55 UN Charter; see in general Universal Declaration on Human Rights (1948), Geneva Conventions on the Laws and Customs of War (1949), International Covenant on Civil and Political Rights (1966) and International Covenant on Economic, Social and Cultural Rights (1966). 
International law already plays an important role in regulating genome editing. Even though there is no international treaty of general application that directly addresses the matter, there are key regional human rights instruments containing specific provisions applicable to genetic interventions, including the Council of Europe's Oviedo Convention on Human Rights and Biomedicine (Oviedo Convention) ${ }^{28}$ and the EU Charter of Fundamental Rights (EU Charter). ${ }^{29}$ There are also important soft law human rights instruments most notably the 1997 UNESCO Declaration on the Human Genome and Human Rights ${ }^{30}$ and the 2005 UNESCO Declaration on Bioethics and Human Rights. ${ }^{31}$

The regional and soft law instruments in the field of biomedicine and human rights indicate that there is an international consensus with respect to certain aspects of genetic interventions. First and foremost, according to all instruments in the field, interventions on the human genome can only be undertaken for preventive, therapeutic or diagnostic purposes ${ }^{32}$ with eugenics being strictly prohibited. ${ }^{33}$ Second, any research and clinical application concerning the human genome ought to be conducted with full respect for human dignity and human rights. ${ }^{34}$ Third, the risks that may be incurred by a person ought not be disproportionate to the potential benefits ${ }^{35}$ and, related to this, there are requirements of rigorous prior risk assessment, adequate risk management and minimising the potential risks for the individuals affected. ${ }^{36}$ Fourth, genetic interventions are subject to a strict requirement of informed consent. ${ }^{37}$ Finally, due regard ought to be given to the rights of future generations. ${ }^{38}$

28 Oviedo Convention for the Protection of Human Rights in Biomedicine (n 11).

29 Charter of Fundamental Rights of the EU (7 December 2000) OJ C 326 26.10.2012, at 391.

30 UNESCO Universal Declaration on the Human Genome and Human Rights (n 11).

31 UNESCO Universal Declaration on Bioethics and Human Rights (19 October 2005).

32 Oviedo Convention, art 13; UNESCO Declaration on the Human Genome, art 12(2) and 15; UNESCO Declaration on Bioethics and Human Rights, art 12(b).

33 Art 2(3) EU Charter of Fundamental Rights. See also domestic laws, ie France, art 16-4 Code civil (1804) (as amended March 2017) and art 214-1, Code Penal (as amended April 2017); Hungary, The Fundamental Law of Hungary (2011) art 3(3); India, Ethical Guidelines for Biomedical Research on Human Subjects (2006) Ch VI, section III(iv). See also USA v Karl Brandt et al. (Case No. 1) The Doctors' Trial, Nuremberg Military Tribunal, Judgment of 19 July 1947.

${ }_{34}$ Art 1 and 2, Oviedo Convention on Human Rights and Biomedicine; art 10, UNESCO Declaration on the Human Genome and Human Rights; art 3, UNESCO Declaration on Bioethics and Human Rights. $\quad 35$ Art 16, Oviedo Convention on Human Rights and Biomedicine.

36 Art 17, Oviedo Convention on Human Rights and Biomedicine; art 5, UNESCO Declaration on the Human Genome and Human Rights; art 20, UNESCO Declaration on Bioethics and Human Rights.

37 Art 5, Oviedo Convention on Human Rights and Biomedicine; art 5, UNESCO Declaration on the Human Genome and Human Rights and art 6, UNESCO Declaration on Bioethics and Human Rights.

${ }^{38}$ Art 16, UNESCO Declaration on Bioethics and Human Rights; Preamble, para 1, Oviedo Convention on Human Rights and Biomedicine; and art 6, UN Declaration on the Responsibilities of the Present Generations Towards Future Generations 1997. 


\section{REGULATORY AND POLICY CHALLENGES POSED BY GENOME EDITING}

The principal regulatory challenges that need to be addressed are: (1) Should the research and clinical application of germline editing be allowed and if so, under what conditions, given the scientific uncertainty regarding the safety of the new technology both for the individuals subject to it and for future generations? (2) Would allowing the clinical application of genome editing open the floodgates for non-therapeutic uses of the new technology, such as enhancement, military purposes or even eugenics? (3) How should the possible negative social effects of genome editing be addressed, including the risk of exacerbating social inequalities if the new technology is not made accessible on an equitable basis, and the resulting danger of genetic discrimination? (4) How can the regulation of genome editing accommodate the varying ethical, cultural and religious positions of different States and stakeholders?

\section{A. Policy Challenges and Responses}

The recent development of more precise, much easier-to-use and cheaper genome editing technology has prompted much debate among scientists, ethicists and policy-makers, ${ }^{39}$ some calling for a moratorium on its use clinically to modify the human germline and establish a pregnancy, ${ }^{40}$ whilst others have called for more extensive use. ${ }^{41}$ Responses from commentators have also been mixed. According to some, genome editing could 'remake' the world ${ }^{42}$ in light of its radical implications for medicine and reproduction, while others warn of the dangers of its abuse, such as the possible surge of 'designer babies'. ${ }^{43}$ There seems to be a growing consensus, however, that any decision on the clinical use of genome editing should be preceded by a broad and inclusive public debate. ${ }^{44}$

39 See eg An International Summit on Human Genome Editing was held in the USA in December 2015; Nuffield Council on Bioethics, 'Genome Editing and Human Reproduction: Social and Ethical Issues' (2018); Second International Summit on Human Genome Editing, November 2018 (n 4). See also H Ledford, 'Bitter Fight over CRISPR Patent Heats up' (2015) 529 Nature 265.

40 See International Bioethics Committee, UNESCO 'Report of the IBC on Updating Its Reflections on the Human Genome and Human Rights' (2015) 28, para 118; International Summit on Human Genome Editing (n 39) para 3 and Second International Summit on Human Genome Editing (n 4) para 6; American Society of Human Genetics, 'Position Statement on Human Germline Genome Editing' (2017), para 1 and most recently, Lander et al. (n 26) and WHO Statement (n 3). $\quad{ }_{41}$ Nuffield Council on Bioethics (n 39).

${ }^{4}$ Wired, 'Easy DNA Editing Will Remake the World. Buckle Up' at <http://www.wired.com/ 2015/07/crispr-dna-editing-2/>.

43 P Ball 'Designer Babies: An Ethical Horror Waiting to Happen?' The Guardian (8 January 2017).

44 European Group on Ethics in Science and New Technologies, 'Statement on Gene Editing' (2016) at 2; Nuffield Council on Bioethics, 'Genome Editing and Human Reproduction' (n 39) at 160, Recommendation 3 and at 162, Recommendation 8; and Second Summit on Human Genome Editing (n 4) para 10. See also art 28 Oviedo Convention on Human Rights and Biomedicine. 
A number of international organisations have issued policy statements on genome editing, highlighting the challenges it presents and proposing different degrees of limitations on the research and clinical application. There is some disagreement as to whether research involving germline editing should be allowed at all. UNESCO and the EU are in favour of allowing basic research involving germline editing, ${ }^{45}$ as are a number of States. ${ }^{46}$ With respect to clinical research and clinical applications involving the new technology, UNESCO's International Bioethics Committee and the WHO have proposed a moratorium on germline editing that could result in a pregnancy and be passed on to future generations, due to the 'unique and unprecedented ethical and technical challenges'. ${ }^{47}$ The broad condemnation of Dr He's experiment seems to evidence an agreement that germline editing should not be used clinically at present. The broader policy question is whether it should be prohibited as a general rule or by way of a temporary moratorium until such time as its use becomes safe and acceptable, or if not, what standards should apply to it.

International organisations and non-governmental scientific organisations seem to agree that there is a need to establish an effective regulatory framework designed specifically to govern genome editing. Two expert bodies were set up in response to the announcement of Dr He's experiment. First, the WHO established a multi-disciplinary expert advisory committee to examine the scientific, ethical, social and legal challenges associated with genome editing and to develop a global framework for the coordination of regulation, legislation and policies in the field. ${ }^{48}$ The WHO Committee called for the establishment of a global registry for all research involving genome editing ${ }^{49}$ and stressed that 'it would be irresponsible at this time for anyone to proceed with clinical applications of germline editing'. ${ }^{50}$ Second, the US National Academies of Sciences and Medicine and the UK Royal Society convened an International Commission on the Clinical Use of Human

45 Reg (EU) No 1291/2013 establishing Horizon 2020, art 19(3)(b) and Nuffield Council on Bioethics, 'Emerging Biotechnologies: Technology, Choice and the Public Good (2012 Report) Ch 3.

46 The UK Human Fertilisation and Embryology Authority granted the first licenses for basic research involving the editing of genes of embryos in 2016 to study gene function in the early development of embryos and help understand the causes of pregnancy failures. See E Callaway, 'UK Scientists Gain License to Edit Genes in Human Embryos' (2016) 530 Nature 18. See also Japan, Guidelines on Gene Therapy Clinical Research, sections 3 and 6; Mexico, General Law on Health 1997, Title 5, art 103 bis 6 . The USA doesn't prohibit germline editing but would not fund any research which uses the new technology, viewing it 'as a line that should not be crossed'; see Statement on NIH Funding of Research Using Gene-Editing Technologies in Human Embryos (28 April 2015) at: <https://www.nih.gov/about-nih/who-we-are/nih-director/ statements/statement-nih-funding-research-using-gene-editing-technologies-human-embryos $>$.

47 WHO Statement on Governance and Oversight of Genome Editing (n 3).

48 'Human Genome Editing', Comment by the WHO Expert Advisory Committee (8 November 2019) at: <https://www.who.int/ethics/topics/human-genome-editing/ethics-explore-options-forglobal-governance.pdf?ua=1>. editing/en/>.

49 At $<$ https://www.who.int/ethics/topics/human-genome50 (n 3). 
Germline Genome Editing. ${ }^{51}$ According to its Statement of Task, the Commission is working on identifying the potential applications of germline editing and appropriate protocols for evaluating its effects in practice. ${ }^{52}$ The title of the Commission and its Statement of Task contain a somewhat premature implicit acceptance of the legality and desirability of the clinical application of the new technology. Given the scientific, legal and ethical uncertainties underlying genome editing, the more cautious stance of the WHO Committee seems preferable. Unsurprisingly, scientists have called on the two bodies to speak with one voice..$^{53}$

Dr He's experiment gave rise to a number of policy suggestions by scientists and medical organisations which emphasised different aspects of the challenges which need to be addressed. One of the main concerns relates to the purpose of the experiment. Scientific associations expressed serious concerns that Dr He's intention was not to cure the human embryos or prevent the transmission of HIV from the parents since there was no real risk of this, but rather to enhance an otherwise health embryo. ${ }^{54}$ This was seen as a dangerous use that could pave the way to eugenics, ${ }^{55}$ as well as failing the risk/benefit analysis given that there were other ways of addressing HIV and that editing the gene increased the risk of other infections. ${ }^{56}$ The other key concern was the lack of common regulatory standards concerning clinical genome editing, ${ }^{57}$ with some proposing the creation of an international registry of all planned or ongoing experiments, ${ }^{58}$ whilst others calling for a modification of the UNESCO Declaration on the Human Genome to prohibit the application of human genome editing until it is deemed safe and effective, as well as to limit it to specified therapeutic applications. ${ }^{59}$ Other scientists have argued that an international treaty banning the clinical uses of genome editing would be too rigid a response, advocating for a voluntary moratorium on the clinical use of the new technology, and the establishment of a coordinating body under the auspices of the WHO to foster discussions and provide regular information on the relevant developments. ${ }^{60}$

Overall, there is broad agreement that there is a need for new and effective international regulation of both the clinical research and the clinical application of human germline editing. The new framework ought to address whether clinical research involving germline editing is permissible, the

\footnotetext{
51 https://www.nationalacademies.org/our-work/international-commission-on-the-clinical-useof-human-germline-genome-editing.

53 Editorials, 'Germline Editing Needs One Message' (2019) 575 Nature 415.

54 See eg Consensus Statement of European Societies of Gene and Cell Therapy on the Reported Birth of Genome-Edited Babies (2018) 29(12) Human Gene Therapy 1337, 1338. See also S Ryder, '\#CRISPRbabies: Notes on a Scandal' (2018) 1(6) The CRISPR Journal 355.

55 Statement from ARRIGE Steering Committee on the possible first gene-edited babies (3 December 2018) and Cyranoski et al. (n 3).

${ }^{56}$ Lander et al. (n 26) 166.

57 Nuffield Council Statement (n 7); Second Summit on Genome Editing (n 4) para 9; Consensus Statement (n 54) 1338.

59 ARRIGE Statement (n 55).

58 Second Summit on Genome Editing (n 4).

${ }^{60}$ Lander et al. (n 26) 168.
} 
purposes for which it can be used, the appropriate safety threshold, the acceptable levels of risk, the risk /benefit analysis for the individual and society, and establish an appropriate institutional framework for oversight.

The international policy responses seem to favour introducing regulation specifically addressing the new CRISPR Cas-9 technology for germline editing. An alternative approach could be to regulate heritable interventions in the human genome more generally. This would be preferable since new genetic engineering technologies are likely to be developed over time. ${ }^{61}$

\section{B. Legal Challenges and Current Landscape}

Somewhat surprisingly given its significance, and save for a few policy statements, ${ }^{62}$ there has been very little direct regulatory response by States. ${ }^{63}$ There is no generally accepted or clearly defined threshold of safety or acceptable risk that is required before the clinical application of genome editing is allowed. Nor is there a common understanding or definitions of the key concepts involved, ie 'the human genome', 'gene', 'germline', 'embryo' ${ }^{64}$ or indeed 'eugenics'. There is no agreement on how to balance the risks and the benefits for the individual and for society and a disturbing lack of clarity concerning the purposes for which germline editing could be used. Therapeutic and preventive purposes seem to be the generally accepted whilst eugenics are prohibited (although this term remains undefined). Between these poles, what constitutes 'enhancement', 'prevention' and 'therapy' for diseases is unclear. ${ }^{65}$ There are no clear legal distinctions between what constitutes a 'disease' as opposed to a naturally occurring mutation, let alone what is a 'serious disease' which might change the risk/ benefit balance. ${ }^{66}$ For example, whether deafness is a disease is medically

61 See eg the recent development of prime editing as a more precise technique in AV Anzalone et al., 'Search-and-replace genome editing without double-strand breaks or donor DNA' (2019) 576 Nature 149.

62 See Australian Government, Department for Health, Third Review of the Gene Technology Scheme (2018); Statement from the Danish Council on Ethics on Genetic Modification of Future Humans in Response to the CRISPR technology (2016); German Ethics Council, Intervening in the Human Germline (2019); Indian Council of Medical Research, National Guidelines for Stem Cell Research (2017); The Netherlands Commission on Genetic Modification, 'Editing Human DNA. Moral and Social Implications of Germline Genetic Modifications' (2017); Statement Issued by the Spanish Bioethics Committee on Genome Editing in Humans (2019).

63 Nuffield Council on Bioethics (n 39) Ch 3.

64 R Isasi et al., 'Editing Policy to Fit the Genome?' (2016) 351(6271) Science 337, 339.

65 For example, the first task set by the International Commission on the Clinical Use of Germline Editing was to consider the range of potential applications of genome editing, including not only the correction of severe monogenic diseases but also various forms of genetic enhancement. International Commission on the Clinical Use of Human Germline Genome Editing, Statement of Task (n 52) para 1.

66 Dr He himself compared his clinical trial to vaccine-like disease prevention in order to justify that it was ethical (He Jiankui 'Designer Baby Is an Epithet' (25 November 2018) Youtube at: $<$ https://www.youtube.com/watch? $=$ Qv1svMfaTWU\&frags $=$ pl $\% 2 \mathrm{Cwn}>$ ). However, many saw 
and legally contested, particularly by the Deaf community. ${ }^{67}$ It is also uncertain whether the use of the technology is reserved for peaceful purposes or whether it could have military applications, for example the creation of enhanced soldiers - be they super strong or resistant to chemical and biological weapons. There is also no clarity concerning access to the new technology, which raises issues of equality and solidarity.

Currently there is a patchwork of domestic laws and guidelines that apply to genome editing, ${ }^{68}$ but since most were developed in the 1990 s to regulate gene therapies they are not necessarily adequate to address genome editing. ${ }^{69}$ Since gene therapies are much more expensive, more difficult to undertake and less accessible than genome editing, few States have regulation and, given their low success rates, many States adopted a very restrictive approach. In light of the differences between the two techniques of genetic interventions, it is not certain whether the existing legal landscape is adequate to address germline editing and if it should be applied by analogy. Furthermore, as evidenced by Dr He's experiment, the issue of the effectiveness of domestic regulations is as critical as that of their content.

Domestic laws are not only inconsistent but also, at times, internally incoherent. For example, some States expressly prohibit germline editing for the purposes of procreation through criminal law sanctions, ${ }^{70}$ others impose civil law sanctions, ${ }^{71}$ and others set out the prohibition in non-binding guidelines. $^{72}$ Russia and the EU do not prohibit germline editing but

his experiment as enhancement rather than therapy, reinforcing the need to define if not regulate these blurred boundaries.

67 C Kim, 'Deafness: More Than a Medical Condition' (3 March 2016) Yale Scientific at: <http:// www.yalescientific.org/2016/03/deafness-more-than-a-medical-condition/>.

68 According to one comparative study of 39 States, 29 banned modifying the germline, some such as China, India and Japan in non-binding guidelines; nine domestic laws were ambiguous and one, the USA, did not prohibit it, see M Araki et al., 'International Regulatory Landscape and Integration of Corrective Genome Editing into in vitro Fertilization' (2014) 12(108) Reproductive Biology and Endocrinology 1,8.

69 See eg Israel, Prohibition of Genetic Intervention (Human Cloning and Genetic Manipulation of Reproductive Cells) Law, 5759-1999; Germany, Embryo Protection Act 1990 and Mexico, General Law on Health 1997. See also EU Directive 98/44/EC of the European Parliament and of the Council of 6 July 1998 on the legal protection of biotechnological inventions.

70 See eg Australia, art 15 and 20, Prohibition of Human Cloning for Reproduction Act 2002 (as amended 2008); Israel, Prohibition of Genetic Intervention (Human Cloning and Genetic Manipulation of Reproductive Cells) Law 5759-1999, art 3(2) but art 5(a) allows the Minister for Health to give permission in individual cases; and Germany, Embryo Protection Act 1990, section 5. In general for a comparative survey of 9 States, see R Yotova, 'The Regulation of Genome Editing and Human Reproduction under International Law, EU Law and Comparative Law' Background Report for the Nuffield Council of Bioethics (2018) 45-61 at: <http://nuffieldbioethics.org/wpcontent/uploads/Report-regulation-GEHR-for-web.pdf $>$.

71 France, Art 16-4 Code civil (1804) (as amended March 2017).

72 India, Ethical Guidelines for Biomedical Research on Human Subjects, sections (ii) and (iii); and Japan, Guidelines on Gene Therapy Clinical Research 2002, section 6. 
disincentivise it by making it non-patentable. ${ }^{73}$ There are also States that allow clinical use of the new technology for procreation. ${ }^{74}$ The domestic laws in Mexico $^{75}$ and Japan ${ }^{76}$ are incoherent in that they prohibit research involving genome editing but do not prohibit implantation of embryos that have been edited. ${ }^{77}$ More coherent approaches are found in Germany ${ }^{78}$ and France, where the prohibition is reflected in both the Civil and the Criminal Codes, and methods of germline modifications are non-patentable. ${ }^{79}$

Overall, the current legal landscape does not address any of the key concerns raised by genome editing satisfactorily. There is, then, a pressing need to consider the regulation of genome editing on the international plane. Agreeing on minimum regulatory standards would be the strongest guarantee against the unsafe, unethical and inequitable uses of genome editing.

\section{THE REGULATION OF GENOME EDITING UNDER HUMAN RIGHTS LAW}

International regulation of interventions in the human genome is currently approached through the framework of human rights law. But is the human rights framework sufficient and adequate?

Two regional European human rights treaties regulate genetic interventions directly, the 1997 Oviedo Convention ${ }^{80}$ and the EU Charter. ${ }^{81}$ The rights and principles of general international law that are most relevant to germline editing are the principle of human dignity, ${ }^{82}$ the right to health, ${ }^{83}$ the right to benefit from science ${ }^{84}$ and the prohibition against

73 Russia, Civil Code, art 1349(4), paras 2 and 3 as modified by Federal Law No. 35-FZ, 12.03.2014. Regulation (EU) No. 536/2014 of the European Parliament and the Council on clinical trials of medicinal products for human use (EU Clinical Trials Regulation) art 90.

74 Mexico, art 154 of the Criminal Code prohibits the manipulation of human genes in a manner that modifies the genotype for purposes other than the elimination or suppression of serious diseases or conditions and USA; see Yotova (n 70) 45-8.

${ }_{77}$ Mexico, General Law on Health 1997, art 7.

76 Japan (n 72).

77 Mexico, art 154 of the Criminal Code only prohibits editing of embryos for other than therapeutic purposes. In Japan, such a ban is currently under consideration in the Draft Comprehensive Strategy on Science, Technology and Innovation; see $<$ https://japan.kantei.go.jp/ 98_abe/actions/201906/_00054.html>. $\quad 781990$ Embryo Protection Act, section 5.

${ }_{79}$ Art 16-4 Code Civil prohibiting modifying the germline except for basic research; art 611-18 of the Bioethics Law making the methods for modifying the genetic identity of humans unpatentable and art 214-1, Code Penal defining eugenics as a criminal offence. ${ }^{80}$ (n 11). ${ }_{81}^{89}$ (n 29).

${ }^{82}$ See eg ECtHR in Pretty $v$ United Kingdom, Appl No 2346/02 [2002] ECHR 427, para 65; CJEU in Case C-36/02, Omega Spielhallen und Automatenaufstellungs GmbH $v$ Oberbürgermeisterin der Bundesstadt Bonn [2004] ECR I-9609, paras 34-35; and African Commission on Human Rights, Purohit and Moore v Gambia, Comm No 241/01 (2003) AHRRL 96, para 57.

${ }^{83}$ CESCR, General Comment No 14 (2000): The right to the highest attainable standard of health, E/C.12/2000/4, paras 1, 2, 12.

84 Venice Statement on the Right to Enjoy the Benefits of Scientific Progress and Its Applications, UNESCO (2009) paras 12-15; Report of the Special Rapporteur in the field of cultural rights, Farida Shaheed on 'The Right to Enjoy the Benefits of Scientific Progress and its Applications' A/HRC/20/26 (14 May 2012) paras 6, 24-25; and CESCR, Draft General Comment: Science and Economic, Social and Cultural Rights (2 January 2020) para 89. 
discrimination. ${ }^{85}$ The concept of the rights of future generations, which are not a human right as such but a legal construct expressing intergenerational equity is also relevant. 86

The human rights approach to genome editing is valuable as it is built on the legal and ethical concepts of human dignity, autonomy, equality, and nondiscrimination. Whilst there is no definition of human dignity, there is broad agreement that it is an ethical concept which underpins all human rights. ${ }^{87}$ It is also a normative concept, described by the German Federal Constitutional Court as meaning "that the human being has a right to "social value and respect"". ${ }^{88}$ As the Court said:

Where there is life, human dignity is due; it is not significant whether or not the bearer of life is conscious of his dignity and how to safeguard it him/herself .... ${ }^{89}$

Transposing the Court's jurisprudence on dignity in the context of abortion to the context of germline editing, it could likewise be argued that human dignity prohibits that assertion of either State ${ }^{90}$ or parental power ${ }^{91}$ over the embryo.

Human dignity is an important limitation on both scientific research involving genome editing and its clinical applications. ${ }^{92}$ It plays an important role when balancing the rights of the individual against the broader public interests at stake. It is not clear, however, where exactly should this balance lie or what weight should be given to the respective values.

The 'welfare of the individual' is, though, another ethical concept which is not legally defined. ${ }^{93}$ It is intrinsically linked to the ethical principle of individual autonomy, which signifies self-governance conferring a 'right to act on one's own judgment about matters affecting one's life, without

85 See art 2 ICESCR; and Barcelona Traction Light and Power Company Limited, Second Phase, Judgment, ICJ Rep 1970, at paras 33-34.

${ }^{86}$ Legality of the Use by a State of Nuclear Weapons in Armed Conflict, Advisory Opinion, ICJ Rep 1996, at 66, 244; and Case Concerning the Gabcikovo-Nagymaros Project (Hungary/ Slovakia), Judgment, ICJ Rep 1997, at 7, 78, para 140. See also Waweru v Republic of Kenya, 142 ILR 208, 323-7. See in general UNESCO Declaration on the Responsibilities of the Present Towards Future Generations.

${ }^{87}$ See art 1, Universal Declaration of Human Rights; Preamble, para 2 of the UN Charter; and Purohit and Moore v Gambia, African Commission on Human Rights, Comm No. 241/01 (2003) AHRRL 96, para 57 stating that 'Human dignity is an inherent basic right to which all human beings, regardless of their mental capabilities or disabilities as the case may be, are entitled to without discrimination. It is therefore an inherent right which every human being is obliged to respect by all means possible and on the other hand it confers a duty on every human being to respect this right.'

${ }^{88}$ Decision of 20 October 1992, BVerfGE 87, 209.

89 Judgment of 25 February 1975, BVerfGE 39, 1 and Judgment of 28 May 1993, BVerfGE 88, 203 both concerning abortion. $\quad 90$ ibid. 91 ibid.

92 UNESCO Declaration on Science and the Use of Scientific Knowledge (1999) para 19. See also UNESCO Universal Declaration on Bioethics and Human Rights (1998) Preamble, para 3.

93 According to the Oxford Dictionary, the ordinary meaning of the term denotes 'the health, happiness, and fortunes of a person or group'. Oxford Dictionary online edition at: $<\mathrm{https}: / \mathrm{www}$. lexico.com/en/definition/welfare>. 
interference by others' ${ }^{94}$ Autonomy finds legal expression in the principle of prior informed consent for genetic interventions, which is reflected in all legal instruments in the field, ${ }^{95}$ as well as in the right 'to make decisions, while taking responsibility for those decisions and respecting the autonomy of others' ${ }^{96}$ The principle of consent is, however, difficult to apply in the context of editing embryos. The principles of autonomy and individual welfare play a key role when balancing of rights and duties of individuals and society. Indeed, the welfare of the individual is commonly juxtaposed with the broader public interest. ${ }^{97}$ On the international plane the interest of the international community becomes relevant too..$^{98}$

How to strike the appropriate balance between the interests and welfare of the individual and broader public and international community interests is the key to future regulation of genome editing. Human rights law requires balancing the interests of the individual with those of the public, arguably placing more emphasis on the former ${ }^{99}$ due to their historic development and focus on protecting the individual against the State. One judicially developed tool for striking this balance is the concept of proportionality. ${ }^{100}$ However, this concept places the burden on the State to justify restrictive regulation and this burden could be difficult to discharge in the face of the scientific uncertainties surrounding the use of germline editing. Furthermore, the various human rights instruments in the field of biomedicine strike a different balance between the potentially competing interests of the individual and society. The drafters of the UNESCO Declaration thought that one of its key objectives was to strike the right balance between enabling scientific progress on the one hand and safeguarding human rights on the other. ${ }^{101}$ In contrast, the Oviedo

94 G Dunstan, 'Should Philosophy and Medical Ethics Be Left to the Experts?' in S Bewley and R Humphry Ward (eds), Ethics in Obstetrics and Gynaecology (RCOG Press 1994) 3.

95 See eg UNESCO Declaration on the Human Genome, art 6 and 7; Oviedo Convention, art 59; UNESCO Declaration on Bioethics and Human Rights, art 7-8.

96 UNESCO Declaration on Bioethics and Human Rights, art 5.

97 Black's Law Dictionary defines the term 'public interest' as 'the general welfare of a populace considered as warranting recognition and protection' (10th edn, Thomson Reuters 2014) 1425.

98 This being 'a consensus according to which respect for certain fundamental values is not to be left to the free disposition of States individually or inter se but is recognized and sanctioned by international law as a matter of concern for all States'. B Simma, From Bilateralism to Community Interest (1994) 250 Recueil des Cours de l'Academie de Droit International 233.

99 A McHarg, 'Reconciling Human Rights and the Public Interest: Conceptual Problems and Doctrinal Uncertainty in the Jurisprudence of the European Court of Human Rights' (1999) 62 MLR 671. cf R Alexy, 'Constitutional Rights, Balancing and Rationality' (2003) 16 Ratio Juris 131; J Habermas, Between Facts and Norms (Blackwell Publishing1996) 256-9; and S Greer, "Balancing" and the European Court of Human Rights: A Contribution to the Habermas-Alexy Debate' (2004) 63(2) CLJ 412.

100 J McBride, 'Proportionality and the European Convention on Human Rights' in E Ellis (ed), The Principle of Proportionality in the Laws of Europe (1999) and S Tsakyrakis, 'Proportionality: An Assault on Human Rights?' (2009) 7:3 ICON 468. See in general FJ Urbina, A Critique of Proportionality and Balancing (Cambridge University Press 2017).

${ }^{101}$ UNESCO, Birth of the Universal Declaration on the Human Genome and Human Rights (1999), Second Meeting of the Legal Commission of the IBC, 9 June 1994, 37. 
Convention and the UNESCO Declaration on Bioethics and Human Rights establish the principle of primacy of the human being in the field of biomedicine, meaning that when balancing the rights of the individual with those of science and society, the interests and welfare of the individual should always prevail. ${ }^{102}$ When applied to genome editing, such an approach might support not only enhancement but also eugenics, provided it was in the interests of the embryo irrespective of the potentially devastating social implications. A better balancing tool would be the precautionary approach from environmental law as it places the burden of proof on the entity proposing to use a new technology in the face of scientific uncertainty, as well as the obligation to take all necessary measures to minimise the risks.

This balancing of interests is further complicated by the obvious fact that embryos do not have the capacity to make decisions about their welfare or provide consent. It is true that it is possible to borrow by analogy the concept of parental consent from medical law where parents can act as agents with respect to minors or incapacitated children. ${ }^{103}$ However, it is also arguable that such automatic transposition to germline editing would be normatively undesirable and should only be done with adequate safeguards in place. First, because it could erode the judicially developed concept of embryo autonomy which is opposable not only to the State but also to the parents ${ }^{104}$ in cases where conflict of interests might arise. Second, because it could unduly extend the legal presumption that parents are the best arbiters of what is in the best interest of their child ${ }^{105}$ in the context of a future child and an intervention underlined by inherent risk, scientific complexity and significant uncertainty. Third, because parental consent in medical law relates to therapeutic interventions whereas germline editing could be used for nontherapeutic ends too, which engage the public interest to a much greater extent. And finally, because of the unprecedented large-scale effects of germline editing, which affects not only the future person but also all future generations that will descend from them. Indeed, germline editing raises issues concerning the interests of the embryo, the rights of future generations, the interests of humanity in preserving the human species in its diversity, as well as the potential conflict between the interests of the embryo with those of the parents. These issues are not currently addressed by human rights law ${ }^{106}$ and the concept of human dignity is too broad and abstract to provide sufficient protection: more concrete legal expression needs to be given to the protection

102 art 2, Oviedo Convention and Art 3(2) UNESCO Declaration on Bioethics and Human Rights.

${ }_{103}$ A Maclean, Autonomy, Informed Consent and Medical Law (Cambridge University Press 2009) 75,128 . See also ECtHR case law on parental consent developed under art 8 on the right to private and family life, ie $W v U K$ (1988) 10 EHRR 29, 50 and Glass $v$ UK [2004] 1 FLR 1019 104 (nn 88-91. 105 C Forster, Medical Law (Oxford University Press 2013) 54.

106 On the requirement of public consultation prior to genetic regulation see art 28 Oviedo Convention and art 18 of the UNESCO Universal Declaration on Bioethics and Human Rights. 
of the interests of the embryo, whether through a risk/benefit analysis or through developing a concept analogous to that of the best interests of the child. Given these considerations, the responsibility for decision-making might need to be shared between the parents and the healthcare professionals both acting as agents of the future child under the clear guidance of the law. The initiative for editing the embryo should clearly lie with the parents alone, however the final decision could be made by a body such as the UK Human Fertilisation and Embryology Authority balancing on a case-by-case basis the health, scientific and ethical dimensions of the proposed intervention in light of the best interest of the future child and the broader public interest.

The key challenge in adopting a human rights approach to genome editing is the lack of consensus as to whether an embryo benefits from human rights protection at all. Given the underlying religious, ethical and cultural sensitivities, ${ }^{107}$ during the drafting of the Oviedo Convention it was agreed that the term 'human being' should be understood in the broadest possible sense $^{108}$ and that the purpose of the convention included not only guaranteeing the rights and freedoms of the persons already born but also the protection of the dignity and identity of the unborn. ${ }^{109}$ According to the current case law of the ECtHR, 'the full protection of the right to life starts only with the birth of the child'. ${ }^{110}$ The ECtHR has acknowledged that:

At European level ... there is no consensus on the nature and status of the embryo and/or foetus, although they are beginning to receive some protection in the light of scientific progress and the potential consequences of research into genetic engineering, medically assisted procreation or embryo experimentation. At best, it may be regarded as common ground between States that the embryo/ foetus belongs to the human race. The potentiality of that being and its capacity to become a person ... require protection in the name of human dignity, without making it a 'person' with the 'right to life' .... ${ }^{11}$

Accordingly, genome editing of embryos would not constitute a violation of the ECHR, although eugenics and arguably enhancement would be contrary to human dignity.

\section{A. Germline Editing under Human Rights Law: Restrictions and Entitlements}

There is a widely held view that germline editing is prohibited under human rights law in Europe. For example, the Preamble of the EU Biotech

\footnotetext{
107 Preparatory Works on the Convention on the Protection of Human Rights and Dignity of the Human Being with regard to the Application of Biology and Medicine, Steering Committee on Bioethics, CDBI/INF (2000) 1, 3. 108 ibid 7.

109 ibid 11. The initial reference to protecting the integrity, understood as inviolability, of the unborn was deleted due to the different levels of protection accorded to embryos in domestic laws in the context of research and abortion, 12.

110 ibid 33 quoting the report of the European Commission of Human Rights in Brüggemann and Scheuten $v$ Germany (12 July 1977) DR 10, 100.

111 Vo v France, Application No 53924/00, ECHR 2004-VIII, para 84.
} 
Directive, asserts that 'there is a consensus within the Community that interventions in the human germ line ... offends against ordre public and morality'. ${ }^{112}$ This is largely due to the Oviedo Convention, which, however, has not been ratified by 18 of the of the 47 Members of the Council of Europe, including a number of EU Member States such as Austria, Belgium, Germany, Ireland, Italy, Luxembourg, Malta, the Netherlands, Spain, Sweden and the UK.

The most controversial issue during the drafting of the Convention was the prohibition of germline editing in Article 13 which provides that ' $[\mathrm{a}] \mathrm{n}$ intervention seeking to modify the human genome may only be undertaken $\ldots$ if its aim is not to introduce any modification in the genome of any descendants'. The reasons for this were the scientific uncertainty and unpredictable effects on future generations. ${ }^{113}$ However, there were also calls for leaving open the possibility of authorising germline therapies given the prospect that future scientific advances might permit the prevention of genetic diseases. ${ }^{114}$ The Working Party that drafted the Convention considered allowing germline interventions in exceptional cases, provided: (i) that there was no conceivable alternative that would correct recognised abnormalities, (ii) that the purpose was to alleviate severe human suffering and (iii) that strict standards of reliability and safety were met. ${ }^{115}$ Ultimately, the drafters decided on a temporary prohibition on germline interventions, which could be reviewed in the light of progress in scientific knowledge. ${ }^{116}$ The safeguards were, therefore, not included. Yet, they could be a helpful starting point when considering how to address the safety concerns surrounding genome editing, and also help inform risk/benefit analyses.

Article 13 prohibits interventions which aim to modify the germline, rather than those that do so. This was to allow genetic interventions for the purpose of somatic modification but whose side effects may affect the germline. ${ }^{117}$ Thus the Oviedo Convention permits somatic genome editing for therapeutic or preventive purposes where modifications in the germline are incidental to the primary process.

The Working Party also considered whether to permit research on the germline. There was broad agreement that this ought to be allowed, even by those who considered germline modifications should be prohibited. ${ }^{118} \mathrm{Draft}$ Article 13 was modified to ban specifically the modification of the genome of any descendants, thus implicitly allowing basic research on germ cells which are not used to bring about a pregnancy. ${ }^{119}$ The Explanatory Report affirms that, '[m]edical research aiming to introduce genetic modifications in spermatozoa or ova which are not for procreation is only permissible if

112 Directive 98/44/EC of the European Parliament and of the Council of 6 July 1998 on the legal protection of biotechnological inventions, Preamble, para 40.

113 Preparatory Works on the Convention (n 107) 63. ${ }^{114}$ ibid. ${ }^{115}$ ibid. $\quad 116$ ibid 64.

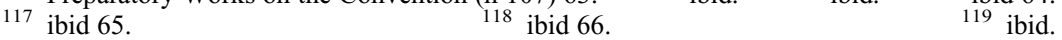


carried out in vitro with the approval of the appropriate ethical or regulatory body'. ${ }^{120}$ Furthermore, neither Article 13 nor Part IV of the Convention regulating the human genome prohibit basic research involving modifications of the genome, provided the edited embryos are not implanted passing the modifications on to descendants. Article 15 also affirms the freedom of scientific research in the fields of biology and medicine, subject to the protection of human rights. It can therefore be concluded that even under the restrictive approach adopted by the Oviedo Convention, basic research involving germline editing is permissible. This reflects the generally held view that freedom of scientific research is universally accepted as a human right. ${ }^{121}$ However, freedom of research is not absolute, ie, Article 15 of the ICESCR permits restrictions on scientific research to protect human dignity and rights, public order, health or morality.

The EU Charter of Fundamental Rights also has provisions directly applicable to genome editing. However, its potential to regulate genome editing in Member States is limited since according to Article 51, the Charter only applies 'to the institutions, bodies, offices and agencies of the Union' and 'to the Member States only when they are implementing Union law'.

The EU Network of Independent Experts on Fundamental Rights, which was set up by the European Commission to monitor fundamental rights in the EU, was tasked to prepare a Commentary on the Charter to provide guidance on its implementation for Member States and EU institutions. ${ }^{122}$ According to the Commentary Article 3 of the Charter, concerning the right to physical and mental personal integrity, should be interpreted broadly and include any form of medical treatment without or against their will. ${ }^{123}$ The Commentary says:

The protection of the embryo against genetic engineering and other unlawful research and the absolute prohibition of any modification in the genome of any descendants illustrates that the protection of the right to personal integrity extends to the unborn child and even to future generations. ${ }^{124}$

This progressive interpretation of Article 3(1) does not find any support in the text itself. It is arguable that if the drafters wanted to include the protection of the embryo against genetic modifications in the provision addressed specifically to biomedicine, they would have done so expressly, just as they prohibited eugenic

\footnotetext{
${ }^{120}$ Explanatory Report to the Convention for the protection of Human Rights and Dignity of the Human Being with regard to the Application of Biology and Medicine, Council of Europe, 15.

121 See art 15(3) of the International Covenant on Economic, Social and Cultural Rights (16 December 1966) 1976 UNTS 993. As of March 2020, the Covenant has 170 States Parties. See also art 12(b), UNESCO Declaration on the Human Genome and art 2(b), Universal Declaration on Bioethics and Human Rights.

${ }^{122}$ The Network consists of one expert per Member State and set up by the European Commission at the request of the Parliament to monitor the implementation of fundamental rights in Member States and the Union.

123 EU Network of Independent Experts on Fundamental Rights, Commentary of the Charter of Fundamental Rights of the European Union (June 2006) 36. 124 ibid 39.
} 
practices and reproductive cloning. Using the concept of future generations to bridge the gap between human rights protection and unborn children is also problematic and not supported by practice. ${ }^{125}$ It can therefore be concluded that the EU Charter does not prohibit germline editing.

The lack of international consensus concerning the prohibition of germline editing under human rights law is further evidenced by the text and preparatory works of the 1997 UNESCO Universal Declaration on the Human Genome and Human Rights (UNESCO Declaration). ${ }^{126}$ Arguably, this is currently the most important international instrument in the field of human genetics, in the absence of an international treaty of general application. While not legally binding, the UNESCO Declaration sets out internationally agreed standards and good practices concerning genetic interventions, which were supported by a broad international consensus at the time of its adoption and are still pertinent today.

The traveaux préparatoires and text of the Declaration show that there was no consensus on prohibiting the research and the clinical application of germline editing at the time of its drafting, when gene therapies were much less effective than today. The Declaration does not prohibit interventions in the human genome or modifications of the germline, despite lengthy discussions of proposals that it should. ${ }^{127}$

The basic assumption of the drafters was that the human genome should be the object of special protection, in order to safeguard the integrity of the human species. ${ }^{128}$ Following an international consultation with States, however, the idea that the human genome should be inviolable was abandoned, due to the potentially beneficial effects of genetic interventions. ${ }^{129}$ As regards clinical research, however, it was felt that given the state of scientific knowledge, 'any experiment designed to transmit to future generations human genetic characteristics modified by human intervention is ethically unacceptable, even for therapeutic purposes'. ${ }^{130}$ It was ultimately decided not to include germline editing in the Declaration's list of practices which are prohibited for being contrary to human dignity. ${ }^{131}$ However, there was a strong perception that clinical research would be inappropriate and unethical less sufficient scientific progress to make it safe. In light of the recent developments in genome editing, it

125 B Weiss, On Fairness to Future Generations (UN University Press 1989) 36. There are 149 UNTS-registered international treaties containing a reference to 'future generations' none of which uses the concept of future generations to extend human rights to unborn children. See also UN Declaration on the Responsibilities of the Present Generations Towards Future Generations 1997.

126 The UNESCO Declaration was adopted unanimously by the General Conference of UNESCO in 1997 and endorsed by consensus by the UN General Assembly, GA Res. 53/152 (9 December 1998) United Nations Resolution on the Human Genome and Human Rights, paras 4 and 6.

127 UNESCO, Birth of the Universal Declaration (n 101), Project of an International Instrument, 47.

128 ibid.

129 ibid, Sixth Meeting of the Legal Commission of the IBC (25 January 1996) 62.

130 ibid 68.

131 Art 11, UNESCO Declaration. 
would be desirable to revisit the debate and ascertain whether there is still a consensus regarding the permissibility of heritable interventions in the human genome.

Even though human rights law does not directly prohibit germline editing, it does impose certain requirements on States. The UNESCO Declaration together with its preparatory works suggest that there might be a positive obligation on States to regulate high-risk genetic interventions, such as genome editing, in order to ensure they are in accordance with human dignity, human rights and the rights of future generations. ${ }^{132}$ Similarly, the Oviedo Convention contains a number of provisions requiring States to legislate to give it effect domestically. This could be seen as an affirmation of the existence of a positive obligation on States under general international law to regulate genetic interventions in order to ensure their safety and compliance with human rights. Indeed, according to the Committee on Economic, Social and Cultural Rights, States parties to the ICESCR are required to regulate in order to prevent the negative effects of science and scientific research on medicine, life sciences and associated technologies. ${ }^{133}$ Related to this are the requirements of maximising the benefits for individuals affected and minimising any possible harm ${ }^{134}$ through processes of risk assessment and risk management ${ }^{135}$ and the obligation to give due regard to the impact of life sciences on the rights of future generations. ${ }^{136}$

There are also human rights that could be used as an argument in favour of using the technology and be relied upon directly by parents should the technology become clinically available, including the right to health, the rights of disabled people and the rights of the child. ${ }^{137}$

The right to health has been interpreted as entailing an obligation to "enable women to go safely through pregnancy and childbirth and provide couples with the best chance of having a healthy infant'. ${ }^{138}$ If this broad construction of the right is accepted, it could be relied on by parents with genetic diseases to argue for genetically editing their reproductive cells or embryos to provide them with the best chance of having a healthy child. The rights of the child could also be used by parents to call on the State to 'ensure to the maximum extent possible the survival and development' 139 of their future child. Such use of these rights would give expression to the principle of individual autonomy but would need

132 UNESCO, Birth of the Universal Declaration (n 101) International Consultation, 71.

133 CESCR, General Comment No 17 (2005), E/C.12/GC/1712, para 35 and Draft General Comment on Science and Economic, Social and Cultural Rights (n 84) paras 56 and 76.

134 UNESCO Universal Declaration on Bioethics and Human Rights, art 4 Benefit and Harm.

135 ibid, art 20 Risk Assessment and Management.

136 ibid, art 16 Protecting Future Generations. See also UN Declaration on the Responsibilities of the Present Generations Towards Future Generations 1997, art 6 Human Genome and Biodiversity and UNESCO Declaration on Science and the Use of Scientific Knowledge 1999, para 39.

137 For detailed analysis of the implications of each of these rights to genome editing see Yotova (n 70) 8-33.

${ }^{138}$ Commission on Human Rights, Report of the Special Rapporteur on the right of everyone to the enjoyment of the highest attainable standard of physical and mental health, E/CN.4/2004/49, para 18.

139 Convention on the Rights of the Child (1989) 1577 UNTS 3, art 6. 
to be carefully balanced with the broader public interests on a case-by-case basis.

The rights of disabled people are an expression of the principles of human dignity, equality and autonomy. They require respect for difference, acceptance of persons with disabilities as part of human diversity and respect for the right of children with disabilities to preserve their identity. ${ }^{140}$ Accordingly, disabled parents cannot be required to edit their embryos in order to remove a disability. Furthermore, States ought to carefully consider the preservation of human genetic diversity and the identity of disabled people when deciding on the permissible therapeutic uses of genome editing.

Overall, it can be concluded that germline editing is presently not prohibited under human rights law and that freedom of basic research in the field is protected. However, given the current state of scientific knowledge, the clinical research or applications involving modification of the germline could be contrary to human dignity, the rights of parents and intergenerational equity. Furthermore, States are under a positive obligation to regulate genome editing domestically in order to ensure its compliance with human dignity and human rights, as well as to protect the affected individual, future generations and society at large from the possible negative effects of the new technology. If and when germline editing becomes clinically available, States should ensure its regulation is in full accordance with existing human rights and the dignity of the future person.

\section{B. The Lawful Purposes of Genome Editing under Human Rights Law}

All human rights instruments in the field of genetics specify that genetic interventions should only be allowed for therapeutic purposes. Article 13 of the Oviedo Convention provides that interventions seeking to modify the human genome 'may only be undertaken for preventive, diagnostic and therapeutic purposes'. The main objective of the drafters was to limit interventions in the human genome to those undertaken for the protection of health. ${ }^{141}$ There was broad agreement that no intervention 'shall be permitted for the purpose of perfecting human existence (rendering human beings more intelligent, musical, athletic, etc)'. ${ }^{142}$ According to the Council of Europe's Explanatory Report ' $[\mathrm{t}]$ he ultimate fear is of intentional modification of the human genome so as to produce individuals or entire groups endowed with particular characteristics and required qualities.' ${ }^{143}$ This detailed definition of the permissible aims of genetic interventions is preferable to the more general wording of the UNESCO Declaration, which refers to relief from suffering but

\footnotetext{
140 Convention on the Rights of Persons with Disabilities (2006) 2515 UNTS 3, art 3.

141 Preparatory Works of the Convention (n 107) 63.

143 Explanatory Report to the Convention (n 120) 14.
} 
also to the improvement of the health of individuals and humankind as a whole. The latter phrase blurs the lines between therapy and enhancement.

The EU Charter specifies that in the fields of medicine and biology there is a 'prohibition of eugenic practices, in particular those aiming at the selection of persons'. ${ }^{144}$ This approach is narrower than that of other human rights instruments as it does not rule out lesser forms of enhancement. With respect to the scope of the prohibition of eugenic practices, the Presidium explained during the drafting of Article 3(2) that it refers to those practices aiming at the selection of persons in serious situations involving "campaigns for sterilisation, forced pregnancy, compulsory ethnic marriage' as carried out in Nazi Germany and in Bosnia and Herzegovina. ${ }^{145}$ According to the Commentary, however, less serious forms of eugenic practices would also be covered and the prohibition should apply not only to States, but also to nonState actors. ${ }^{146}$ The Commentary further specifies that Article 3(2) should be construed as a specific limitation on the freedom of research, including clinical research, under Article 13 of the EU Charter. ${ }^{147}$ Given that the term 'eugenic practices' is not defined in the text of the EU Charter or in its Commentary, and in light of the examples given by the Presidium, it is not clear what lesser forms of eugenics might fall within the prohibition and whether it would extend to all other forms of enhancement, including those undertaken at the initiative of private individuals, that is parents, rather than States. This uncertainty is reinforced by the broad ordinary meaning of the term 'eugenics' used by scientists. According to the Oxford Dictionary, it denotes ' $[t]$ he science of improving a population by controlled breeding to increase the occurrence of desirable heritable characteristics' ${ }^{148}$ Whilst Dr He's clinical trial would certainly fall within this definition, it might not fall under the meaning of Article 3(2) of the EU Charter.

The UNESCO Declaration too limits the purposes of genetic research allowing research which affects the genome and does not have any direct health benefit only if it is intended for the benefit of others and is compatible with human rights. ${ }^{149}$ The purposes of clinical applications of genetic research on humans are even more restricted - they ought to seek to relieve suffering and to improve the health of individuals and humanity as a whole. ${ }^{150}$ During the drafting of the Declaration, a number of States emphasised the need to regulate strictly the purposes of genetic interventions so as to prevent any eugenic abuse or the use of genetics for military

\footnotetext{
144 Art 3(2)(b) EU Charter of Fundamental Rights of the European Union, 2000/C Official Journal of the European Communities 364/01.

145 Commentary to the EU Charter (n 124) 40. 146 ibid.

147 Commentary to the EU Charter (n 123) 37.

148 English Oxford Dictionary Online edition at: <https://en.oxforddictionaries.com/definition/ eugenics>.

149 Universal Declaration on the Human Genome and Human Rights, UNESCO, 11 November 1997, art 5(e). 
purposes. ${ }^{151}$ The declaration reflects the broad international consensus that genetic interventions in the human genome may only be undertaken for scientific, therapeutic or diagnostic purposes. ${ }^{152}$

It can be concluded that under international human rights law, genetic interventions can be only be undertaken for therapeutic, preventive and diagnostic purposes, with eugenics being strictly prohibited $^{153}$ and enhancement being implicitly excluded from the lawful applications. These limitations apply both to the research and to the clinical applications of genome editing. International law, however, does not contain definitions of the key terms, ie 'therapy', 'prevention', 'enhancement' or 'eugenics'. Any future instrument in the field ought to fill this gap.

\section{The Social Effects of Genome Editing: Equality and Solidarity}

Another key concern is access to the new technology and how to prevent it from replicating if not exacerbating social inequalities. Human rights instruments have approached this in different ways. The Oviedo Convention is innovative in this respect, with Article 3 providing for equitable access to health care. The drafters considered this to be an important application of the principle of nondiscrimination, meaning that, 'Parties could not refuse a disabled person equitable access to health care even if such care costs more than average.' 154 However, the provision was not intended to create an individual right enforceable against the State but to affirm an economic and social objective subject to the available resources and the needs of the individual concerned. ${ }^{155}$ Article 3 of the Oviedo Convention could be seen as a regional example of good practice, addressing the broader equality challenges posed by new healthcare technologies while leaving regulatory space for States to determine whether access would be open, free or equitable. It is to be hoped that this approach would be followed in any new instrument regulating genetic interventions.

The right to benefit from science and the right to health are also relevant here. The right to health is a fundamental human right found in numerous universal human rights instruments. ${ }^{156}$ The Constitution of the WHO defines 'health' as 'a state of complete physical, mental and social well-being and not merely the absence of disease or infirmity'. ${ }^{157}$ The CESCR's General Comment No 14 on the Right to the Highest Attainable Standard of Health emphasises that

151 UNESCO, Birth of the Declaration (n 101) Sixth Meeting, 62 and Eighth Meeting, 109.

152 ibid, Sixth Meeting, 62.

153 Eugenics are also prohibited under international criminal law as crimes against humanity and war crimes. See USA v Karl Brandt et al. (Case No. 1) The Doctors' Trial, Nuremberg Military Tribunal, Judgment of 19 July 1947, at 175-9. See also the 'Nuremberg principles' regarding permissible medical experiments endorsed by the Military Tribunal during the Doctors' Trial, at

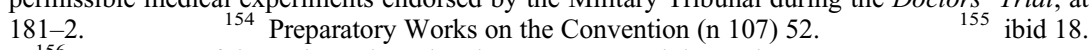

156 See art 25 of the Universal Declaration on Human Rights and art 12 ICESCR.

157 Constitution of the World Health Organisation (22 July 1946) Preamble, para 2. 
accessibility is one of the essential elements of the right, ${ }^{158}$ defining it as both physical and economic, ie affordability. ${ }^{159}$ The CESCR underlines that 'States have a special obligation to provide those who do not have sufficient means with the necessary ... health care facilities'. ${ }^{160}$ Therefore, the obligation of providing equitable access to health care facilities could have important financial implications for States which introduce genome editing at the clinical level, requiring them to make it affordable to socially disadvantaged groups irrespective of whether it is a publicly or privately provided service. This conclusion is further reinforced by the right to benefit from science and its applications set out in Article 15 of the ICESCR which requires States to provide access to scientific advances to everyone within their jurisdiction. According to the Special Rapporteur in the Field of Cultural Rights, 'States should ensure that the benefits of science are physically available and economically affordable on a non-discrimination basis.' ${ }^{161}$ The draft General Comment on the right requires States to ensure 'fair access' to science and its applications, ${ }^{162}$ as well as open access to scientific information. ${ }^{163}$ While not binding, these interpretations are persuasive. Yet, the regulation of access to and sharing of scientific benefits and applications at the inter-State level is much more loose, ${ }^{164}$ highlighting that the human rights framework does not currently adequately address the challenge of solidarity between States.

The UNESCO Declaration addresses the challenges of equality and solidarity in a different way, drawing on the concept of the 'common heritage of humanity' found in the international law of the sea ${ }^{165}$ and applying it to genetic governance. The drafters considered this to be both the cornerstone and the main innovation of the declaration. ${ }^{166}$ The definition of the human genome as common heritage was the most debated aspect of the instrument. For some, declaring the human genome the common heritage of humanity meant protecting the rights of the individual in the field of genetics. Others saw the concept as entailing an obligation to protect the human genome itself in its past, present and future expressions as a source of diversity and genetic evolution. ${ }^{167}$ Some thought that, when applied to the human genome, the concept of the common heritage could create a tension between the

\footnotetext{
158 CESCR, General Comment No 14 (2000): The Right to the Highest Attainable Standard of Health, E/C.12/2000/4, para $12 . \quad 159$ ibid. 160 ibid, para 19.

161 Report of the Special Rapporteur in the field of cultural rights, Farida Shaheed on 'The Right to Enjoy the Benefits of Scientific Progress and Its Applications' A/HRC/20/26 (14 May 2012) paras 26-30. 162 Draft General Comment (n 84) para 23.

164 See the much weaker requirement of international co-operation under art 15(4) ICESCR, including the sharing of scientific benefits and transfer of technologies between developed and developing or underdeveloped States. The ICESCR merely recognises the benefits of such cooperation but falls short of mandating it.

165 See 1982 United Nations Convention on the Law of the Sea, 1833 UNTS, Part XI 'The Area' 3 and 1954 UNESCO Convention for the Protection of Cultural Property in the Event of Armed Conflict, 3511 UNTS, Preamble and art 1.

166 UNESCO, Birth of the Declaration (n 101), Third Meeting of the Legal Commission of the IBC (19 September 1994) 50.

167 ibid, Fourth Meeting, 54.
} 
individual heritage of the person and that of the species as a whole. ${ }^{168}$ There were also those who feared that qualifying the human genome as common heritage could allow States to take authoritarian measures in the fields of public health and demographic policy, limiting the right of individuals to procreate freely and transmit their genetic heritage to their descendants, or compelling individuals to undergo diagnostic, preventive or therapeutic operations in the interests of society. ${ }^{169}$ One group cautioned against equating the human genome to an economic resource whose use must be controlled at the international level. ${ }^{170}$ Others countered that the genetic information contained in the genome was a resource and that the right to exploit it in the common interest belonged to the international community as a whole. ${ }^{171}$ The qualification of the human genome as common heritage of humanity was also addressed in the comments of a number of States. Some emphasised that the human genome was first and foremost the property of the individual while others responded that they did not recognise ownership over the human body. ${ }^{172}$ The UNESCO International Bioethics Committee ('IBC') that drafted the Declaration clarified that the concept of common heritage did not automatically exclude the possibility of patenting genome research, which helps stimulate further research, but was meant to emphasise the principle of freedom of access to scientific knowledge concerning the genome, to genomic research data and to its results. ${ }^{173}$

It was ultimately agreed that the common heritage concept denoted the need to establish a dynamic balance between the protection of individual rights and the common interest of humanity, and that the two values were indivisible and mutually reinforcing. ${ }^{174}$ Further, the concept of common heritage was seen as an affirmation that the human genome is a universal value whose safeguarding is the duty of the international community, taking into account its individual and collective, tangible and intangible diversity. ${ }^{175}$ In this context, the IBC also considered the concept of 'future generations' as being part of 'humanity' and, as such, a subject of international law that had rights and responsibilities towards itself, ${ }^{176}$ including the obligations to protect genetic diversity. ${ }^{177}$ In addition, the IBC emphasised the importance of the principle of solidarity in this field, in particular the sharing of knowledge derived from scientific research. ${ }^{178}$

Treating the human genome as the common heritage of humanity addresses both the challenge of solidarity within the State and between States, as well as

168 ibid, Seventh Meeting, 99.

169 ibid, Sixth Meeting, 63 and International Consultation, 69, 71.

170 ibid, International Consultation, $69 . \quad 171$ ibid, Seventh Meeting, 100.

172 ibid, Fifth Meeting, 58.

173 ibid, 59 and Sixth Meeting, 62 and International Consultation, 70.

174 ibid, Fifth Meeting of the Legal Commission of the IBC (25 September 1995) 58 and International Consultation, $69 . \quad 175$ ibid 74.

176 ibid, Fourth Meeting of the Legal Commission of the IBC (27 April 1994) 54.

177 ibid, Third Meeting, 50.

178 ibid 30 and 35. 
that of balancing the interests of the future individual with those of humanity. However, as evidenced in the preparatory works of the UNESCO Declaration, this concept is not universally accepted and its implications give rise to controversies. Furthermore, the concept of the common heritage was originally developed in the law of the sea as a tool for the common management of resources and thus centres around the principle of nonappropriation. ${ }^{179}$ It is therefore difficult to transpose it automatically to something as intrinsically linked to the individual as the human genome without running the risk of its commodification. It would therefore be worth revisiting the concept of common heritage when discussing any new instrument concerning genetic interventions or finding an alternative concept that would address the challenges it was intended to address. Such an alternative could be the global public goods, understood as 'those whose scope extends worldwide, are enjoyable by all with no groups excluded, and, when consumed by one individual are not depleted for others'. ${ }^{180}$ Treating the human genome as a global public good would promote access to knowledge and data, encourage peaceful and beneficial applications in the field of human genetics, and emphasise the broader public interest.

The rights of future generations is another concept which addresses solidarity challenges on an intergenerational scale. The concept originated in environmental law and is commonly found in environmental treaties, ${ }^{181}$ as well as in some treaties relating to the protection of cultural heritage. ${ }^{182}$ More recently, the concept started being used in instruments regulating science and human health. ${ }^{183}$ According to the UN Declaration on the Responsibilities of the Present Generations Towards Future Generations, in the field of the human genetics the concept entails an obligation to ensure that scientific and technological progress do not impair or compromise the preservation of the human species. ${ }^{184}$ UNESCO declarations in the field provide for obligations to give due regard to the impact of life sciences on the rights of future generations. ${ }^{185}$

The 'rights' of future generations are not really rights as such, as there is no legal rights holder, nor do the so-called 'rights' have a substantive content. Instead they are a legal construct expressing a general principle of

179 cf A Pardo, 'Who Will Control the Seabed?' (1968) 47 Foreign Affairs 123; and G Hardin, 'The Tragedy of the Commons' (1968) 162 Science 1243.

180 Human Genome Organization Ethics Committee, 'Statement on Human Genomic Databases' (2002) $1 . \quad 181$ See art 3 of the Rio Declaration on Environment and Development (1992).

182 According to the UNTS database, 149 international treaties contain a reference to the rights of future generations only one of which links them to human health in the context of managing radioactive waste.

${ }^{183}$ See eg Preamble of the Oviedo Convention requiring that progress in medicine is used for the benefit of future generations.

${ }^{184}$ UNESCO Declaration on the Responsibilities of the Present Generations Towards Future Generations (12 November 1997) art 6.

${ }^{185}$ Universal Declaration on Bioethics and Human Rights, art 16; and UNESCO Declaration on Science and the Use of Scientific Knowledge, para 39. 
intergenerational equity and imposing procedural obligations on States to act with due diligence with respect to activities likely to affect future generations and prevent harm to them. The rights of future generations are relevant to the regulation of genome editing as the technology will have an inevitable, significant but uncertain impact on them. Accordingly, States ought to regulate germline editing as a high-risk genetic intervention that will impact upon the rights of future generations. In particular, they ought to take into account the possible impacts of genome editing on the rights of future generations when making decisions concerning both its legality and permitted applications, as well as to act with due diligence to prevent harm to those rights. This could be achieved through continuous impact assessments of the possible long-term consequences, risk-monitoring, risk-management and constant re-evaluation when authorising specific applications of genome editing. As highlighted by the Aarhus Convention, ${ }^{186}$ which regulates environmental matters, another way of ensuring respect for the rights of future generations is providing public access to relevant scientific information and allowing public participation in decision-making. ${ }^{187}$ This approach could be applied by analogy to genome editing.

Turning to the more granular level, a particular legal manifestation of the principle of equality is the prohibition against discrimination. While it is arguable that genetic discrimination is already prohibited under the umbrella of the general principle of non-discrimination, biomedical legal instruments also do so explicitly. Article 11 of the Oviedo Convention prohibits any form of discrimination against the person based on their genetic heritage, the key concern being that genetic diseases, or even the predisposition to them, might become a means of selection and discrimination. ${ }^{188}$ Article 21 of the EU Charter also prohibits discrimination on various grounds, including genetic features. ${ }^{189}$ Some States, such as Canada, have passed specific laws prohibiting genetic discrimination defined as requiring an individual to undergo or disclose the results of a genetic test as a condition for providing goods, services or entering into a contract. ${ }^{190}$ Indeed, the first reported legal case concerning genetic discrimination in China failed on the ground that discrimination on the basis of genetic features was not considered to fall under the general prohibition against discrimination in the Chinese Constitution. ${ }^{191}$

In order to address equality challenges, any future instrument regulating the human genome and genetic interventions should expressly prohibit discrimination based on genetic characteristics, specifying that this also

\footnotetext{
186 Aarhus Convention on Access to Information, Public Participation in Decision-Making and Access to Justice in Environmental Matters (25 June 1998). ${ }^{187}$ ibid, art 1.

188 Explanatory Report (n 120) $12 . \quad 189$ Commentary of the EU Charter (n 125) 191.

190 Genetic Non-Discrimination Act (S.C. 2017, c. 3) section 3.

191 Tang, Zhou, Xie v Human Resources and Social Security Bureau in Foshan City (2010) Foshan, Intermediate, Administrative, Final reported in Z Xie, Labour Law in China: Progress and Challenges (Springer 2015) 45.
} 
entails a ban on requiring individuals to undergo genetic tests as a condition for entering into a contract or being provided with goods and services.

\section{Genome Editing under Human Rights Law: Critical Appraisal}

While it is true that all international instruments addressing genetic interventions to date purport to regulate them from a human rights perspective, the implications of this framework for genome editing and its adequacy to address the challenges it poses remain open to question. The main difficulty, which was highlighted during the drafting of the UNESCO Declaration, the Oviedo Convention and the EU Charter, is the applicability of human rights in the absence of a legally recognised 'person' in the period before birth, let alone to the future generations of this person. While human rights are valuable and important for the protection of persons in relation to somatic genome editing, the germline seems to mostly escape their safety net.

The second challenge presented by the human rights framework is that of striking the right balance between the rights of the individual(s) concerned (in germline editing cases, these would be the parents) and the broader public interest. As exemplified by the express provision on this in the Oviedo Convention, from the perspective of human rights law the rights of the individual will always prevail over the interests of science and society.

Thirdly, human rights are mostly territorial in that States are obliged to respect, protect and promote them with respect to persons within their jurisdiction and a purely human rights approach cannot itself bridge the gap between scientifically developed and developing States, nor guarantee solidarity and equitable access. A global public goods or common heritagebased approach would promote solidarity and equitable access more effectively, giving due weight to the common interests at hand.

Fourthly, human rights do not define the safety threshold that needs to be met before the technology becomes clinically available, nor the acceptable levels of risk or harm. These aspects of genome editing could be regulated by drawing from relevant principles of environmental law that have been recognised to apply to human health, including the precautionary approach, ${ }^{192}$ the requirement of prior impact assessment, ${ }^{193}$ the rights of future generations and the principle of no harm. ${ }^{194}$ A distinct advantage of drawing on environmental law in this context is that it places the burden of proving the

192 See Principle 15 of the Rio Declaration on Environment and Development (1992) UN Doc A/ CONF.151/26 (Vol I). On the applicability of the principle to the protection of human health, see Case C-180/96, United Kingdom v Commission, ECJ (5 May 1998) at 2265.

193 See Principle 17 of the Rio Declaration. On the applicability of the principle to medicine and life sciences see art 20 of the Universal Declaration on Bioethics and Human Rights.

194 See Principle 2 of the Rio Declaration. On the applicability of the principle to biotechnology, see Agenda 21, UN Conference on Environment and Development (3-14 June 1992) Rio de Janeiro, Brazil, para 15.3 . 
safety and efficacy of the new technology on those seeking to use it. In contrast, a human rights-based proportionality analysis places the burden of proving that the technology is not sufficiently safe or effective to use on the State that wants to impose regulatory limits.

Finally, and possibly most problematically, human rights only create direct obligations for States and State entities. Given recent trends in funding, research and developments in science and technology, it is highly likely that the major breakthroughs in genome editing will be made and put into practice by private entities. ${ }^{195}$ Accordingly, it is up to States to legislate to make sure that human rights continue to apply to individuals and corporations working in the field of biomedicine, ideally before genome editing clinical trials and applications are made available to the general public.

This is not to say that human rights are not an indispensable part of the regulatory framework for genome editing. But they need to be developed further to protect the embryo and complemented by other standards to ensure the safe and equitable use of genetic interventions. As seen in the UNESCO Declaration and the two European human rights treaties, there are a number of human rights and principles compliance with which is critical to ensure that the new technology is used for the benefit of human beings, namely the principle of respect for human dignity, the prohibition against genetic discrimination, the freedom of scientific research and the right to equitable access to healthcare.

\section{CONCLUSION}

Given that recent scientific and technological developments have brought humanity much closer to being able to genetically engineer future persons and edit out diseases, there is a pressing need for effective regulation of the human genome and genetic interventions on both the international and domestic planes. A future instrument would need to set out a general rule as to whether human germline editing is to be allowed and if so, in what circumstances and under what conditions. As evidenced in the temporary ban of germline editing in the Oviedo Convention and the lack of prohibition in the UNESCO Declaration on the Human Genome, no consensus could be reached in the past that germline genome editing should be prohibited under international law. However, the significant scientific progress that has since taken place in the field of human genetics has created a momentum for exploring regulatory options and for ascertaining whether that lack of consensus still exists. The recent experiment by Dr He, coupled with the responses by scientists and policy-makers, provide a strong incentive for States to discuss and agree on common international standards for genetic

195 eg Dr He's experiment was conducted in and approved by the Shenzhen HarMoniCare Women and Children's Hospital, which is the largest private maternity medical institution in China. 
interventions in order to make genome editing safe, respectful of human dignity and human rights, as well as to enable scientists to develop their research. Indeed, the existing instruments in the field of human genetics already indicate the crystallisation of a positive obligation on States to regulate highrisk genetic interventions. One flexible approach could be the imposition of a temporary moratorium on the clinical trials and the clinical application of genome editing, while expressly preserving the scientific freedom to conduct basic research in order to make the technology safe for future clinical use. An international debate and consensus would be required in order to lift such moratorium. Another approach could be to allow clinical research involving germline editing on a case-by-case basis, through a centralised decisionmaking process, based on clearly defined criteria, subject to prior impact assessment and subsequent risk management.

Genome editing should, at the minimum, be subject to compliance with human dignity and human rights, as well as to a strict risk/benefit analysis which balances the interests of the future individual, of their parents and those of society, humanity and future generations. Striking the correct balance would help promote the health and welfare of individuals and their descendants while ensuring social equality and the survival of the human species in its genetic diversity. The exact balance between those potentially competing considerations can only be struck on a case-by-case basis, taking into account the seriousness of the genetic defect that is being targeted, the availability of alternative therapies, the likelihood of success and the risk of possible negative effects for the embryo and their descendants, as well as the public interest in maintaining genetic diversity, equality and solidarity. Striking the balance too much in favour of the individual could lead to using genome editing to enhance the descendants of those who can afford it, creating a superior human race-or, indeed, species. It could also lead to homogenising the human genetic pool, making it vulnerable to extinction by a single disease or genetic defect. Overemphasising the public interest, on the other hand, could result in denying life-saving therapies, the right to procreate and the right to health.

The regulatory instruments from the 1990s show a broad general agreement that genetic interventions ought to pursue strictly therapeutic purposes, ruling out eugenics, military ends and enhancement. What the existing instruments fail to provide, however, is a clear indication as to how to distinguish between therapy and enhancement. Accordingly, any future instrument in the field should define more clearly the key terms and the boundaries between them. In practice, it might be helpful to define the permissible uses of germline editing on a more granular level, ie should it be undertaken only in the event of a 'disease' or a 'serious disease'? Should consideration be given to available alternative therapies, which may be less risky but also more expensive? What is the acceptable level of risk of harm to the future person and their future generations? And finally, who should decide on whether the 
criteria are met - a national or an international body or, indeed, solely the parents exercising their reproductive autonomy? In light of past experience with gene therapies, it might be preferable to allow germline editing only as a last resort and in the absence of reliable alternative therapies. Given the easy accessibility of CRISPR Cas- 9 and its increasingly wide use in basic research, it might be advisable to have a centralised international decisionmaking body to give approvals for clinical uses of the technique and ensure the consistent application of international standards.

If States adopt a permissive approach to genome editing, this would necessitate institutional oversight to help ensure it is effective and meaningful. Such a mechanism could be organised under the auspices of an existing international organisation such as the WHO or UNESCO or in the form of a treaty body. The oversight mechanism could be endowed with both administrative and regulatory powers, enabling it to adopt binding regulations in this fast-developing field. ${ }^{196}$ Alternatively, it could take the form of a less coercive compliance committee such as those established under environmental agreements with regulatory powers conferred on a Conference of States Parties. ${ }^{197}$ States could be required to deposit all permissions that they give for research involving genome editing, relevant data collected and research outputs in order to foster equitable access and scientific progress. The decision-making body might be able to provide recommendations or binding directions if any permission granted was not in accordance with international law. Such a decision-making body should be comprised not only of lawyers but also include scientists and ethicists.

Procedurally, it would be desirable to initiate a broad international debate in order to shape international standards involving as many States as possible, including in particular those States that are currently active in germline editing research, such as China, Russia, the US and the UK. Adherence to such standards would be key to building public trust in the new technology, legitimising its use and gaining a positive international reputation in the field. ${ }^{198}$

\footnotetext{
196 Similar to those of the International Seabed Authority under the UN Convention on the Law of the Sea (n 165) arts 151-155.

197 See eg ongoing negotiations of the Intergovernmental Conference on Marine Biodiversity in Areas Beyond National Jurisdiction discussing the establishment of a platform for the sharing of information, scientific data and good practices, as well as a scientific committee to promote coherent decision-making at: $<$ https://www.un.org/depts/los/biodiversity/prepcom.htm>.

198 ie, the negative international response to Dr He's experiment had a high reputational cost for China, which most likely motivated its retrospective withdrawal of the approval of the experiment (see Approved File of Ethical Committee ChiCTR1800019378, 30 November 2018) and the sentencing of Dr He to three years of imprisonment (see "China jails "gene-edited babies" scientist for three years' BBC News (30 December 2019) at: <https://www.bbc.co.uk/news/ world-asia-china-50944461>). Russia's Ministry of Health denounced the clinical use of germline editing as premature in response to the WHO's Expert Advisory Committee call on regulators not to allow any further work until the implications have been properly considered
} 
The international debate should include not only States but also scientists, NGOs, specialised international organisations, industry and persons carrying genetic diseases. This could be done under the auspices of UNESCO, the WHO or through an ad hoc conference. The conference could draft a binding treaty or a soft law declaration setting out internationally agreed standards applicable to genome editing and paving the way to a future binding instrument. Given the complex scientific character of the object of regulation, such a treaty could be drafted by an ILO-style tripartite conference, including States, scientists and affected individuals. The conference could also draft a model law on genome editing to help guide the regulatory approaches of States with respect to the new technology given that domestic law and its effectiveness are the main safeguard for the lawful and ethical use of genome editing. Such a model law should set out a minimum threshold of protection for the embryo, acknowledging its human dignity and drawing inspiration from the key relevant human rights, such as the right to health, the right to benefit from science, the principle of no harm and/or the principle of the best interest of the future child. It is unlikely that an agreement could be reached on whether the integrity of the embryo ought to be protected, given the very different approaches in this respect in the context of abortion. Due to the sensitive cultural, social, religious and ethical issues involved in protecting the embryo, any international instrument on genome editing should leave States sufficient latitude to address this themselves. This could be achieved by setting out minimum international standards that should apply to genome editing and the protection of embryos based on the broadly accepted general principles of human dignity and equality, while allowing States to provide higher standards of protection and to flesh out the specific implications of these principles. Alternatively, the future instrument could set out stricter and more detailed standards but allow States to derogate from them based on cultural, religious or moral grounds. It is to be hoped that such an instrument would combine an approach based on human dignity and rights with a global public goods or common heritage regime to promote solidarity and equitable access, as well as with relevant principles inspired by environmental law in order to ensure the safety of the new technology.

following the announcement of Dr Rebrikov—-see WHO, 'Human Genome Editing' Comment (n 48). 